\title{
Identification and Prioritization of the Components of the Entrepreneurship Education System in Technical and Vocational Schools.
}

\author{
Professor Dr. Sorush Niknamian \\ Board Member of Weston A Price Foundation (WAPF), Washington DC, US \\ Corresponding E-mail: so.niknamian@gmail.com
}

\begin{abstract}
The purpose of this research was Recognising and prioritising Components of ntrepreneurship education system in technical and vocational schools. To do this research, has been used the combined research method with exploratory design (one of a variety of mixed research projects). First, using interviews with entrepreneurship professors and Delphi technique, entrepreneurship education system indicators were identified in vocational schools and compiled using component coding. The formal validity, the content validity ratio (CVR), and the coefficient of agreement of the initial questionnaire were obtained and were prepared for remittance in a small section. After completing a questionnaire, a sample size of 30 subjects was obtained and the results were extracted using SPSS software. Total reliability was obtained. The statistical population of the research was 1 entrepreneurship specialists (entrepreneurship lecturers at different universities of the country) in the qualitative section and 2- students in technical and vocational schools in llam province. In the qualitative section, sampling was done through purposeful sampling and in the quantitative section, stratified cluster sampling was performed. The results of the study, using exploratory and confirmatory factor analysis and modifying the qualitative results, identify 9 components of the entrepreneurship education system in vocational and technical vocational schools, which are the percentage of variance and specific value respectively: entrepreneurship education, psychological characteristics of students, academic and professional counseling, leadership style, management and organization of vocational schools, communication with industry and commercial and managerial skills, attention to content, development of entrepreneurship skills in learners, space and educational equipment, and teaching methods. Friedman's test results showed that the prioritization of the components has a significant difference.
\end{abstract}

Keywords: Identification, prioritization, entrepreneurship education system, technical and vocational school. 


\section{Introduction}

The evidences indicate that those communities, which rely on human resources and their education system versus natural resources, may act more successfully in the long run (Oguz \& Aydin, 2012:620). Nowadays, entrepreneurship is called as a variable that plays a key role in the economy (Naderi, 2015:17). The analysis on today changing world and variation of position for the governments, organizations and individuals identifies that the community needs to individuals with entrepreneurial skills today thereby to enable them to tackle with the living challenges in modern world. The entrepreneurship is assumed as one of the important and endless sources for human communities. It is a source, which returns to potential and creativity in the humans, as low cost on the one hand and endless factor, on the other hand. Enjoying entrepreneurial spirit and entrepreneur manpower is one of the factors today that may transform economic and social and industrial appearance of a country (Rouhi, 2014:3). The modern world countries are surely exposed to wide national, regional and international changes, developments and threats and guarantee and survival for these nations it requires for entrepreneurs who can infuse fresh blood into body of national economy in the long term and take efficient step toward development (Alvani, 2011:5). The quantity and quality of their investment in skill-driven education is deemed as one of the foremost signs of accelerating movement of a country to realize balance and sustainable development. It is entirely obvious that it is doubly necessary for such an investment in techno-vocational high schools and knowledge-work education centers in which many students are involved every year. Such attention originates from this point that today the techno-vocational high schools are seriously addressed by educational sponsors as main centers to train work production potential and capability of entrepreneurial citizens (not work-seeking students) in developed countries (Bagherifar, 2016:2). The Ministry of Education has paid due attention to improving entrepreneurial spirit and proposed some strategies to develop and internalize it as the main cornerstone for training of human capitals within developments in the present world (Aghababaeian, 2013:1). Growth and development of techno-vocational trainings and knowledge-work education or in other words technical and vocational high schools is one of the examples for operationalizing of such strategies for which entrepreneurship is considered as a distinct feature of such types of trainings (Naderi, 2015:18).

Since 1970s, many European and American developed countries have argued that reduced economic growth and failure in international competitions has been typically affected by performance of education and training system (Bagherifar, 2016:2). The problem of unemployment is assumed as a barrier against development path for developing countries and as the paramount economic-social challenges as well as one of the foremost threats for national security and development of the nations (Naderi, 2015:40). One of the reasons for unemployment of academic graduates is the lack of acquisition of skill and training profession, which is directly related to type of education and educational system (Pahlavi, 2014:3). The given experiences may show that despite paying attention to entrepreneurial 
trainings in the universities, such trainings have been always exposed to serious and several problems and they could not create the necessary motive for setup entrepreneurial businesses in the academic graduates (Ojaghi, 2016: 44-45). The results of study done by Khodabandehloo (2010) indicated that according to attitude of students, the technovocational high schools could not prepare the ground for training entrepreneurship for them at favorable level. Nonetheless, the conducted analyses by Pezeshkirad and Mohtasham (2003) indicate that the graduates as the outputs of educational system lack the needed capabilities and they tend to employment, especially in public sector instead of creating occupational opportunities and entrepreneurship and participation in national development (Ojaghi, 2016: 40-410. Unfortunately, instead of being entrepreneurial, Iranian educational system practically creates business-seekers so that fewer entrepreneurs may be trained under such an educational system. The achievement point and objective lies in this point that entrepreneurial culture should be internalized at different levels of society, particularly among the educated class and employee-training culture, which has resulted from inadvertent and unplanned employments over recent decades, should be replaced with creativity and entrepreneurship culture (Vatankhah, 2015:17).

The entrepreneurship culture may serve as one of the most influential techniques to transfer easily educated population to work market. The evidences show that rising of proper trainings may decrease unemployment (Ojaghi, 2016:40). Training of entrepreneurship is one of the technical fields for improving employment for the youths undertook by International Labor Organization (ILO) (Shekari, 2016:34). The universities may be entrepreneurs by creating flexible, creative and innovative climate and act flexibly versus changes and developments (Manero and Egido, 2014:153). Codification and execution of comprehensive entrepreneurship and skill-training plan has been designated for all educational courses, especially students at high schools in their educational curricula as the operational strategies listed in document for fundamental development in Educational system in the given draft. According to School Outlook Document in 2025, the school is assumed as the center for presentation of teaching and training services and opportunities to students, particularly in terms of entrepreneurial dimension. By virtue of upstream documents, the educational system is missioned and responsible for providing the needed manpower from the society concerning business for which a lot of sources are consumed every year for skilltrainings in terms of financial, and human-related dimensions by taking entrepreneurial approach in the techno-vocational high schools. Lack of appropriate planning and model for training entrepreneurship in techno-vocational high schools may cause wasting the aforesaid sources and is led to low- quality in educational system for job-seekers graduates versus entrepreneurs. In the course of general policies of production and supporting from Iranian business and capital, and with respect to statements of Supreme Leader about importance and position of economy in meeting individual and social requirements during recent years and especially calling 2017 as the year of 'Resistive economy an, production and employment', and knowledge-based economy, implementation and execution of national 
comprehensive scientific plan and rising share of production and exportation of products and given the entrepreneurial experiences of national and provincial entrepreneurs active in production and employment, and with respect to the existing gaps in quality of training entrepreneurship in techno-vocational high schools as it mentioned above and given the high rate of unemployment in Iran as well as necessity for proposing of entrepreneurship training model in the afore-said techno-vocational high schools, the researcher decided to identify elements of entrepreneurship training system in techno-vocational high schools by conducting a qualitative- quantitative study. Recognizing these factors may be utilized to analyze status quo in entrepreneurship training system in the techno-vocational high schools by decision-makers, especially educational and curricular planners and educational executives and thereby to contribute to improvement of quality of trainings.

\section{Theoretical and researching bases}

There are numerous entrepreneurial development policies in the world. Some of these policies include knowledge creation and development, entrepreneurial attitude, behavior and culture in society and training of entrepreneurship etc. (Rahmati, 2010:9-10). Entrepreneurship is a process by which the entrepreneur proposes new product and service by accepting to take risk through giving new idea for creating business (Saeedikia, 2016:16). Entrepreneurship is trainable but this question may be raised how to do it. The entrepreneurship should be trained beyond business project (Gutiérrez \& Baquero, 2017).

Educational system is deemed as one of the important social systems in any country. In addition to convey cultural heritage and human experiences to new generation, this system is missioned to exert favorable changes in cognitions, attitudes and finally behavior of children, adolescents and youths. Review on history of entrepreneurship may show that many researchers believe entrepreneurship process is trainable (Fayolle \& Gailly, 2008; Kuratko, 2005; Hindle, 2007; Fiet, 2001) and thereby one can lead the individuals toward (Mohammad Kazemi, 2016: 45). The experiences of entrepreneurship trainings indicate in most of countries that the entrepreneur can be trained by education (Naderi, 2015; quoted from Peikarifar \& Mahnegar, 2012:18). Paying due attention to improvement of educational system is one of the effective factors in developing entrepreneurship. Today, training and developing entrepreneurship has special position almost in all developed and developing nations at all educational grades (Rahmati, 2010:9). The studies indicate that actualizing entrepreneurship and creating entrepreneurship spirit in individual is the foremost effective factor in entrepreneurial movement by training (Yadollahi Farsi, 2009:95). As a simple definition, training of entrepreneurship is a systematic, conscious and object-oriented process by which non-entrepreneurs are creatively trained by their potential. In fact, training of entrepreneurship is an activity that is used for transferring the knowledge and information needed for entrepreneurship that will be followed by increase, improvement and development of attitudes, skills and capabilities of non-entrepreneurs (Shah Hosseini, 2009:83). Such trainings are really proposed to train creative and innovative individuals. 
Such trainings tend to use suitable given opportunities, risk-taking, tendency to solve problems, improvement of motives and derives in individuals (Saeedi Mehabad, 2008:61). Training of entrepreneurship provides knowledge, motivation and skill necessary for starting and advancement of trend of a successful business (Dahmardeh et al., 2015; after Cho, 1998:2). The studies on this subject show in Europe that such trainings could bring up more accountable individuals and convert them to entrepreneurs or thinkers in the field of entrepreneurship. As a result, rate of unemployment and failure has been reduced for businesses (Dahmardeh et al, 2015; quoted from Orbano et al, 2008:2). Therefore, interpretation of entrepreneurship becomes highly important in order to train more individuals in the course of entrepreneurship and improvement of their entrepreneurial capabilities (Dahmardeh et al., 2015:2). Various models have been so far proposed concerning training entrepreneurship e.g. entrepreneurship training model (Hynes, 1996), entrepreneurship training pyramidal model, entrepreneurship training circular model, and entrepreneurship training model (Hytti and O'Gorman, 2004), entrepreneurship training centralized or gravitational model (Streeter, 2003), entrepreneurship training decentralized or radial model (Streeter, 2003) etc. which are mainly adjusted to training of entrepreneurship in universities and among them two entrepreneurship training models (Hynes, 1996) and (Hytti \& O'Gorman, 2004) are mainly illustrated because they are more proportional to be trained in techno-vocational high schools.

The entrepreneurship training model (Hynes, 1996): Hynes has posited a process in a table for curricula of entrepreneurship training and expressed that the precise objectives should be designated for knowledge, skill and learning to achieve the goals in entrepreneurship plan. Similarly, one should distinguish between some concepts e.g. 'with whom to learn' and 'what should be learned'. This table comprises of students' data: The bases of previous knowledge (motive, personality, needs/ interests, independence, attitudes, parental effect, self-respect, and occupational values and experiences), training contents (definition of entrepreneurship, internal entrepreneurship, innovation, developing a new product, teamwork, business, and marketing and management), teaching method: training (pedagogical, study and lectures), skill creation (Group discussion, case studies, presentations, problem-solving, simulation, teamwork, and projects), discovery (brainstorming, personal targeting, occupational and counseling planning), and results: personal (secure relation), knowledge (venture business, self-employment, business, management, market analytical skills, problem-solving, decision-making, relationship, riskability), and occupational (improved knowledge, more extensive job choices, unstructured occupational outlook) (Dahmardeh, 2015:4-5).

The entrepreneurship training model (Hytti \& O'Gorman, 2004): In a study which was carried out by Hytti and O-Gorman, a model was presented for training of entrepreneurship including training objectives and contents of this model. They included objectives (learning of entrepreneurship concept, learning of entrepreneurship process and being entrepreneur) and content (action done by entrepreneur, entrepreneurship nature, requirement for 
entrepreneurs, entrepreneurship sources, value creation in the existing organizations and professions, development and skill and way of startup a small profitable business) (Dahmardeh, 2015:6). Several factors influence in training of entrepreneurship including: 1Curricula in schools for improving entrepreneurship should comprise of all learning experiences and opportunities which are analyzed and executed formally and informally under supervision and responsibility of educational system to exert favorable change in knowledge, skills and attitudes of students and their performance and efficiency should be evaluated (Aminzadeh, 2015:145), 2- curricular content, and 3- Skill of entrepreneurial instructors. By implementation of polling for instructors in various universities, Hills (2002) found that majority of them believed those individuals should teach entrepreneurship lessons in these courses that have exercised entrepreneurial business experiences and or at least have background in working with entrepreneurs. Many researchers have mentioned that the lack of empowered schools is deemed as one of the challenges in training of entrepreneurship at higher education level (Ojaghi, 2016:47). 4- Plans and policies: Today, university is no longer assumed as a place only for learning a series of teachings. Barton Clark argues that in twenty first century, those universities are dynamic which can be entrepreneurial and they can integrate expert and managerial values together (Ojaghi et al., 2016; quoted from Clark, 2003:47). 5- Practical tools: Nowadays, various educational tools should be also utilized for training of entrepreneurship in addition to diversified educational techniques. 6Psychological empowerment: Psychological empowerment is a process for improving sense of competency in personnel by recognizing and removing the conditions caused their disability. Psychological empowerment denotes the process of rising internal motive to do the assigned tasks in four cognitive dimensions including effectiveness, competency, significance and having right for choice (Amirkabiri, 2010:102).

Shmasudin et al. (2016) criticized and analyzed policies and methods for training of entrepreneurship in Malaysia. The findings showed the government has been focused in these dimensions: Improvement of current policies of training of entrepreneurship, presentation of various entrepreneurship plans to increase numbers of young entrepreneurs, and necessity for empowerment to train entrepreneurship in the graduates. Rauch and Hulsink (2015) examined effect of entrepreneurship training on entrepreneurial behavior. Their findings indicated that training of entrepreneurship might be efficient, especially for students who participate in entrepreneurship courses and they might indicate perceived attitude and behavioral control at high level. Similarly, in their study titled 'The elements for developing entrepreneurship training in agricultural higher education system' that was done by Sharifzadeh and Abdullah Zadeh (2015) to identify the objective and prioritization of a group of indicators from entrepreneurship training variables in agricultural higher education field, they classified and ranked 159 indicators in eight variables (development of entrepreneurial training methodology, planning for entrepreneurship training, content of entrepreneurship training, study on entrepreneurship training, occupational development for agricultural entrepreneurship training, practitioners of entrepreneurship training in agriculture, spreading 
entrepreneurship culture and capacity- building and institutional development for training of entrepreneurship) as developmental variables of training of entrepreneurship in agricultural higher education system. In a survey done by Naderi et al. (2015) under title of 'Conceptual modeling for effect of entrepreneurship training variables on attitude of trainees toward business in techno-vocational high schools', they assumed elements of entrepreneurship training as variables including personality traits of trainees, characteristics of mentors, educational climate and equipment, transformational leadership style, academic and occupational counseling, training content, teaching methods and training patterns for trainees in the family. In a study conducted by Khosravipour et al. (2007) under title of 'Identifying and analysis of educational effective factors in entrepreneurial capability of students in Applied Sciences Higher Education Center', they concluded that capabilities of instructors, teaching methods, training content and equipment might be effective educational factors needed to corrections.

\section{Methodology}

The current research aims to identify and prioritize variables of entrepreneurship training system in high schools. The exploratory design was utilized as one type of qualitativequantitative (mixed) research projects. The statistical population of present study includes 1) Academic teachers from various universities in Iran (instructors who taught in entrepreneurship course) in qualitative part; and 2) Trainees in techno-vocational high schools in Ilam Province participated in quantitative part of study Totally 388 respondents: 138 females and 250 males). In qualitative part, 25 respondents were elected among entrepreneurial experts by purposive sampling method and this process was continued using interview and bi-stage Delphi technique up to saturation of information. In quantitative part, 261 trainees from techno-vocational high schools were chosen by means of stratified cluster sampling technique. In the qualitative phase of this study, 12 academic teacher were interviewed. The questionnaire of entrepreneurship training system was administered in techno-vocational high schools with eight items (training of entrepreneurship, psychological characteristics of trainees, educational and occupational counseling, leadership style, management and organization of techno-vocational high schools, relationship to industry and commercial and administrative skills, content, developing of entrepreneurship skills in learners and educational climate and equipment) and 60 indices for implementation in quantitative part based on Likert five-scale spectrum after analysis of massive data resulting from interview, several encoding phases, calculation of content validity rate, polling and determination of adjustment coefficient in sample of qualitative unit ( 25 members). The questionnaire was handed over to 30 testees to compute reliability coefficient (internal consistency of questions) and their results were extracted using SPSS software for which the Cronbach alpha coefficient was at appropriate level.

After administration of questionnaire in data analysis, descriptive and inferential statistical techniques, central tendency indices (mean and median) and discrepancy indicators (standard 
deviation and variance) were employed for describing research data and also exploratory factor analysis was adapted for classification and confirmatory factor analysis was utilized to determine construct validity using questionnaire of entrepreneurship system in technovocational high schools. To achieve research objectives, the following questions were proposed: 1- How can one prepare questionnaire of entrepreneurship training system in techno-vocational high schools? 2- Has questionnaire of entrepreneurship training system the adequate validity and reliability in techno-vocational high schools?

\section{Findings}

After administration and collection of questionnaires in quantitative unit (trainees in technovocational high schools), Exploratory Factor Analysis (EFA) was conducted using SPSS software. In order to classify the items relating to entrepreneurship training system in technovocational high schools and to conduct exploratory factor analysis, KMO test was executed initially to determine adequacy of sample size and Bartlett sphericity test was adapted to analyze factorial potential for data. Their results are given in Table (1).

Table 1- KMO testing results and Bartlett sphericity test

\begin{tabular}{|l|c|c|}
\hline \multirow{3}{*}{ Bartlett sphericity test } & Chi-2 coefficient: & 12439.077 \\
\cline { 2 - 3 } & Degree of freedom (d.f): & 1711 \\
\cline { 2 - 3 } & Significance level: & 0.001 \\
\hline
\end{tabular}

As the findings indicate in Table (1), value of KMO criterion is 0.946 and this value denotes adequacy of sample size for implementation of exploratory factor analysis and research data can be reduced to some infrastructural and fundamental factors. Likewise, result of Bartlett test (12439.077) at significance level (0.001) suggests proper separation of factors based on factor loading coefficients and it shows on the one hand that there is high correlation between internal items of the given factor and on the other hand no correlation is visible between items of a factor and items from another factor. The exploratory factor analysis methodology mainly aims to examine structure of current status in multivariate data. In this analysis, those variables which are highly correlated to each other (positively or negatively) are probably affected by identical items, but the variables that are not almost correlated to each other may be influenced by different elements. Exploratory factor analysis is a statistical technique used for estimation of hidden items or variables on the one hand and reducing great numbers of variables into lesser factors, on the other hand. Thus, analytical technique is used for main variables in order to extract possibly great numbers of observed variables out of fewer factors each of which is interpreted by variables and related significance. The questions were classified into 9 factors using exploratory factor analysis. Then, any factor was nominated according to nature inherent in questions. At next step, we should identify quantity of hidden factors. The results for determination of quantity of hidden factors are given based on eigenvalues in Table (2).

Table 2- Determination of final (total) variance of questionnaire of entrepreneurial education system 


\begin{tabular}{|c|c|c|c|c|c|c|}
\hline \multirow{2}{*}{ Factors } & \multicolumn{2}{|c|}{ Without varimax sum of square } & \multicolumn{2}{c|}{ With Varimax sum of square } \\
\cline { 2 - 7 } & Total & $\begin{array}{c}\text { Variance } \\
\text { percent }\end{array}$ & $\begin{array}{c}\text { Cumulative } \\
\text { percent }\end{array}$ & Total & $\begin{array}{c}\text { Variance } \\
\text { percent }\end{array}$ & $\begin{array}{c}\text { Cumulative } \\
\text { percent }\end{array}$ \\
\hline $\begin{array}{c}\text { 1- Training of } \\
\text { entrepreneurship }\end{array}$ & 25.241 & 42.781 & 42.781 & 8.282 & 14.021 & 14.21 \\
\hline $\begin{array}{c}\text { 2- Psychological features of } \\
\text { trainees }\end{array}$ & 3.783 & 6.412 & 49.193 & 6.353 & 10.768 & 24.789 \\
\hline $\begin{array}{c}\text { 3- Educational and } \\
\text { occupational counseling }\end{array}$ & 2.463 & 4.174 & 53.367 & 5.637 & 9.554 & 34.344 \\
\hline $\begin{array}{c}\text { 4- leadership style, } \\
\text { management and organization } \\
\text { of techno-vocational high } \\
\text { schools }\end{array}$ & 1.994 & 3.380 & 56.747 & 5.117 & 8.673 & 43.017 \\
\hline $\begin{array}{c}\text { 5- Relationship with industry } \\
\text { and commercial and } \\
\text { administrative skills }\end{array}$ & 1.686 & 2.858 & 59.604 & 4.814 & 8.160 & 51.177 \\
\hline 6- Paying attention to content & 1.430 & 2.423 & 62.027 & 4.068 & 6.895 & 58.072 \\
\hline $\begin{array}{c}\text { 7- Developing entrepreneurial } \\
\text { skills in learners }\end{array}$ & 1.209 & 2.049 & 64.076 & 2.407 & 4.079 & 62.151 \\
\hline $\begin{array}{c}\text { 8- Educational climate and } \\
\text { equipment }\end{array}$ & 1.187 & 2.012 & 66.088 & 1.979 & 3.355 & 65.506 \\
\hline 9- Teaching method & 1.047 & 1.774 & 67.862 & 1.390 & 2.356 & 67.862 \\
\hline
\end{tabular}

With respect to Table (2), total quantity refers to eigenvalue. As the findings indicate, variable of entrepreneurship training has the highest eigenvalue (8.272) which interprets the greatest variance (14.021) for the variables and variable of teaching method includes the least eigenvalue (1.390) and it interprets the lowest variance (2.356) for the variables. Based on Keiser's criterion, those variables with eigenvalues less than 1 have been ignored in selection of factors. The results of above-said table also show that we can interpret about $68 \%$ of total variance for entrepreneurship training system in techno-vocational high schools by classification of items and according to 9 different identified variables. The following diagram is SCREE plot. This diagram indicates visually the results of previous table concerning suitable numbers of factors. Similar to criterion of Eigen-status, one can determine number of factors by this chart. As it seen in this chart, 9 factors have eigenvalue higher than one. Namely, total 59 items can be reduced into 9 factors.

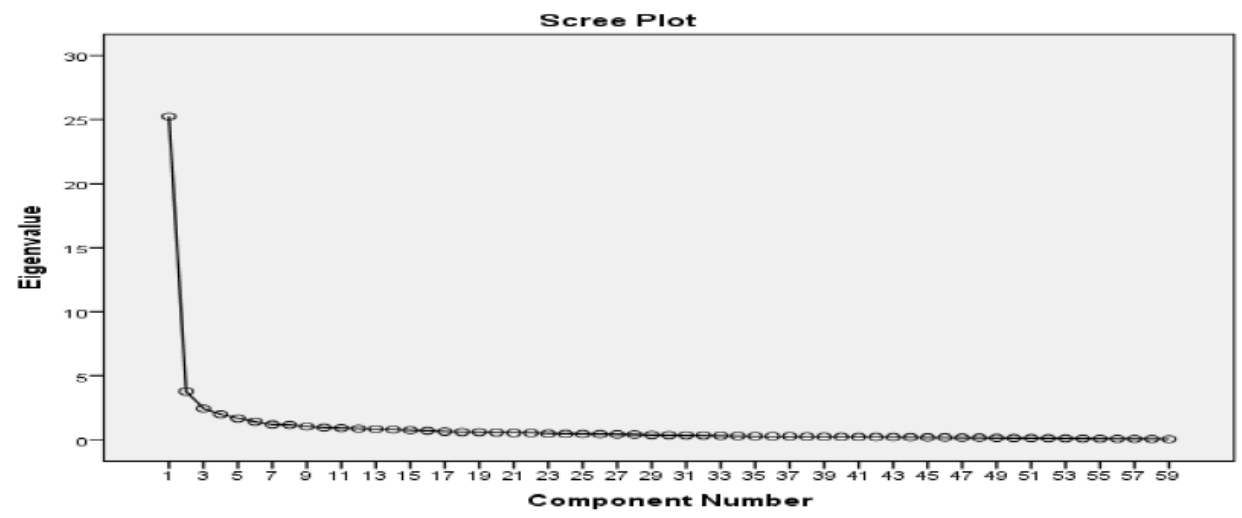

Diagram 1- SCREE chart for showing components of entrepreneurial education system 


\section{Varimax elements matrix}

Table 3- Varimax elements matrix

\begin{tabular}{|c|c|c|c|c|c|c|c|c|c|c|c|}
\hline \multicolumn{2}{|c|}{1} & \multicolumn{2}{|c|}{2} & \multicolumn{2}{|c|}{3} & \multicolumn{2}{|c|}{4} & \multicolumn{2}{|c|}{5} & \multirow{8}{*}{\multicolumn{2}{|c|}{$\begin{array}{l}\text { Components/ } \\
\text { question Nos./ } \\
\text { factorial } \\
\text { loading }\end{array}$}} \\
\hline 1 & 0.732 & 15 & 0.684 & 24 & 0.764 & 30 & 0.709 & 37 & 0.750 & & \\
\hline 2 & 0.642 & 16 & 0.677 & 25 & 0.732 & 31 & 0.707 & 38 & 0.702 & & \\
\hline 3 & 0.637 & 17 & 0.677 & 26 & 0.712 & 32 & 0.684 & 39 & 0.667 & & \\
\hline 4 & 0.631 & 18 & 0.660 & 27 & 0.701 & 33 & 0.673 & 40 & 0,651 & & \\
\hline 5 & 0.616 & 19 & 0.649 & 28 & 0.638 & 34 & 0.649 & 41 & 0.650 & & \\
\hline 6 & 0.614 & 20 & 0.621 & 29 & 0.566 & 35 & 0.606 & 42 & 0.617 & & \\
\hline 7 & 0.609 & 21 & 0.600 & & & 36 & 0.495 & & & & \\
\hline 8 & 0.601 & 22 & 0.491 & & & & & & & & \\
\hline 9 & 0.578 & 23 & 0.482 & 43 & 0.748 & 49 & 0.599 & 55 & 0.707 & 58 & 0.594 \\
\hline 10 & 0.567 & & & 44 & 0.691 & 50 & 0.566 & 56 & 0.664 & 59 & 0.531 \\
\hline 11 & 0.508 & & & 45 & 0.635 & 51 & 0.552 & 57 & 0.730 & & \\
\hline 12 & 0.506 & & & 46 & 0.623 & 52 & 0.549 & & & & \\
\hline 13 & 0.432 & & & 47 & 0.616 & 53 & 0.526 & & & & \\
\hline 14 & 0.407 & & & 48 & 0.496 & 54 & 0.520 & & & & \\
\hline
\end{tabular}

With respect to significance of Bartlett test, Varimax rotation technique was utilized to identify and nominate factor. The results of exploratory factor analysis are slightly consistent with initial classification of items. The results of factor analysis for questionnaire of entrepreneurial education system have been shown in techno-vocational high schools in Table (4) using main components technique.

Table 4- Factor analysis of questionnaire of entrepreneurial education system

\begin{tabular}{|c|c|c|c|}
\hline Fact & Eig & & $\begin{array}{l}\text { interpreted } \\
\text { cumulative } \\
\text { variance }\end{array}$ \\
\hline Fac & 8.272 & 14.021 & \\
\hline \multicolumn{4}{|c|}{$\begin{array}{l}\text { 1- Improving creative spirit by embedding related bases during high school technical course-2- Exploitation } \\
\text { from successful entrepreneurs to convey implicit knowledge to trainees- } 3 \text { - Holding scientific- expert } \\
\text { campuses in order to visit local successful businesses and entrepreneurial centers- 4- Implementation of } \\
\text { practical projects by trainees concerning creation of new businesses during education- 5- Using modern } \\
\text { creative and multiplicative teaching methods for trainees instead of traditional methods- } 6 \text { - Taking } \\
\text { entrepreneurial approach in evaluation of lessons- } 7 \text { - Training of expert entrepreneurs at any discipline using } \\
\text { specialized lessons for the given course- } 8 \text { - Training of entrepreneurial process, induction, encouragement, } \\
\text { and motivation in students as objectives of this education- } 9 \text { - Codification of entrepreneurial training } \\
\text { curriculum with a specific goal and encouraging students to express their idea and cooperation in } \\
\text { establishment or measure for opening an entrepreneurial company-10- Orientation of entrepreneurial bases } \\
\text { toward products and services with relative advantage in the country- } 11 \text { - Training of entrepreneurial mentor } \\
\text { in techno-vocational high schools- 12- Trainees should learn financial affairs management techniques (types } \\
\text { of financial sources, financing, and venture investment)- 13- Making trainees familiar to various scientific } \\
\text { sources and references and communication and idea exchange with entrepreneurial networks and meetings- } \\
\text { 14- To acquire successful entrepreneurial experience by trainees }\end{array}$} \\
\hline Factor 2: Psychological characteristics of trainees & 6.353 & 10.768 & 24.789 \\
\hline \multicolumn{4}{|c|}{$\begin{array}{l}\text { 15- Creation of interest and eager in trainees for research and study by trainees- } 16-\text { Enjoyment of } \\
\text { characteristic of requirement for achievement by trainees as entrepreneurial potential- } 17 \text { - Possessing } \\
\text { features of creativity and innovation by trainees as entrepreneurial potential- 18- Benefitting from high } \\
\text { characteristic of self-confidence by trainees as entrepreneurial potential- } 19 \text { - Having features of riskability } \\
\text { and high tolerance to failure by trainees as entrepreneurial potential- } 20 \text { - Possessing feature of self-reliance }\end{array}$} \\
\hline
\end{tabular}


and internal control by trainees as entrepreneurial potential- 21- Having characteristic of opportunism by trainees as entrepreneurial potential- 22- Benefitting from feature of tolerance of ambiguity by trainees as entrepreneurial potential- 23- Having feature of independence- seeking by trainees as entrepreneurial potential

\begin{tabular}{|l|l|l|l|}
\hline Factor 3: Educational and occupational counseling & 5.367 & $\mathbf{9 . 5 5 4}$ & $\mathbf{3 4 . 3 4 4}$ \\
\hline
\end{tabular}

24- Commissioning of cooperatives, shopping centers and small-size businesses by students on educational site- 25- The presence of experienced educational and occupational advisor-26- Holding educational and occupational counseling sessions for trainees-27- Planning by advisor to invite successful entrepreneurs for lecture in occupational counseling sessions-28- Planning by advisor to identify entrepreneurial interest and talent of trainees and planning to lead them toward entrepreneurship- 29- Planning by advisor for holding local meetings regarding entrepreneurship

\begin{tabular}{l|l|l|l|}
$\begin{array}{l}\text { Factor 4: Leadership style, management and organization } \\
\text { of techno-vocational high schools }\end{array}$ & 5.117 & $\mathbf{8 . 6 7 3}$ & $\mathbf{4 3 . 0 1 7}$ \\
\hline
\end{tabular}

30- Transformational leadership style exercised by principal in techno-vocational high school- 31Participation of trainees and apprentices in making decisions- 32- Principal's expertise, interest and involvement in entrepreneurial process- 33- Spreading entrepreneurial spirit and culture in techno-vocational high schools- 34- Formation of entrepreneurial committee in techno-vocational high schools- 35- Spreading intellectual leadership style in techno-vocational high school- 36- Spreading servicing leadership style in techno-vocational high school

\begin{tabular}{|l|l|l|l|}
\hline Factor 5: Relationship with industry and commercial and & 4.814 & $\mathbf{8 . 1 6 0}$ & 51.177
\end{tabular}
administrative skills

37- Relation among techno-vocational high schools and industry and identifying industries proportional to environmental conditions and invitation from owners of these industries to lecture in sessions with trainees and introducing business and entrepreneurship- 38- Subscription of economic journals and newspapers and establishment of entrepreneurial journal to introduce business and entrepreneurship- 39- Attraction of financial and intellectual supports from holders of industries and entrepreneurial councils for entrepreneurial trainees- 40- Holding some skill-driven classes of technical disciplines in the relevant business and entrepreneurial sites- 41- To make training and learning time more flexible using flexible and online technological trainings- 42- Planning for devotion of more time to practical business and entrepreneurial activities

\begin{tabular}{|l|l|l|l|}
\hline Factor 6: Paying attention to the content & $\mathbf{4 . 0 6 8}$ & $\mathbf{6 . 8 9 5}$ & $\mathbf{5 8 . 0 7 2}$ \\
\hline
\end{tabular}

43- Compliance of curricular content with scientific and technological developments (updated and applied)44- The curricula contents proportional to the jobs and requirements of work market including management and marketing- 45- Flexibility of curricular content and based on technological information and communication developments- 46- The curricular content should improve necessity for achievement and internal control in trainee- 47- The presence of new topics and subjects relating to creativity and entrepreneurship and business in curriculum- 48- Considering entrepreneurial approach in lessons and curricular sources

\begin{tabular}{|c|c|c|c|}
\hline Factor 7: Developing entrepreneurial skills in learners & 2.407 & 4.079 & 62.151 \\
\hline
\end{tabular}

49- Trainees should learn marketing and sale techniques- 50- Trainees should learn formulation of a business project in their studied course- 51- Trainees should possess individual entrepreneurial skills and characteristics- 52- Trainees should be familiar with environmental analysis skills to recognize entrepreneurial opportunities- 53- The trainees should be given sense of self-efficacy in making occupational decisions in training- 54- Trainees should enjoy feature of taking positive attitude toward learning and entrepreneurship as entrepreneurial potential

\begin{tabular}{|l|l|l|l|}
\hline Factor 8: Educational climate and equipment & $\mathbf{1 . 9 7 9}$ & $\mathbf{3 . 3 5 5}$ & $\mathbf{6 5 . 5 0 6}$ \\
\hline
\end{tabular}

55- The presence of standard workshop climate in techno-vocational high schools to present practical trainings- 56- Adequate educational equipment according to the world standards and proportional to any technical discipline- 57- Benefitting from Information Technology IT

\begin{tabular}{|l|l|l|l|} 
Factor 9: Teaching method & $\mathbf{1 . 3 9 0}$ & $\mathbf{2 . 3 5 6}$ & $\mathbf{6 7 . 8 6 2}$
\end{tabular}

58- Participation of trainees in curricular discussions and using their comments (discussion and dialogue)59- Displaying movie and slide and holding educational workshops in techno-vocational high schools and at entrepreneurial centers 
Using exploratory factor analysis and by means of main components analytical method and Varimax rotation, 9 components were extracted with eigenvalue higher than one. Afterwards, any component was nominated according to inherent nature in questions. The results of factor analysis in one of micro-components were deleted because of lower level of factorial loading and finally variance percent of eigenvalue was identified and confirmed according to inherent nature of questions in 9 variables of entrepreneurial education system in techno-vocational high schools respectively. They totally interpreted about $68 \%$ of variance of entrepreneurship education system in techno-vocational high schools. These findings have verified construct validity of questionnaire of entrepreneurial education system in techno-vocational high schools as a multidimensional tool for evaluation and calibration of status quo in entrepreneurial education system in techno-vocational high schools and in fact research conceptual model was drawn. The results of exploratory factor analysis and the extracted components with numbers of questions showing any factor are indicated in Table (4).

\section{Has questionnaire of entrepreneurial education system in techno-vocational high schools the necessary validity?}

The construct validity has been analyzed in the present study using confirmatory factor analysis and it is the only input in factor analysis of the matrix of correlation between variables. This type of factor analysis is calculated by LISREL software. The first-order factorial model was executed under standard approximation and significance t-test. The fitness indices of first-order factor analysis (AGFI $=0.94 ; \mathrm{GFI}=0.92, \quad x^{2} / d f=2.59$, RMSEA $=0.078$ ) showed that all factorial loadings of components are significant along with their sub-variables and they are compliant to conceptual model. This model is well fitted and there is significant relationship among indices and variables. At the next step, we should see if variables of entrepreneurial education system could interpret entrepreneurial education system in techno-vocational high schools or not. To this end, based on data the second-order confirmatory factor analysis was done and second-order factorial model was implemented. The second-order factorial model is defined as a type of factorial models in which the hidden factors are measured using observable variables and they are in turn affected by a more infrastructural variable, namely the hidden variable) but at higher level. We conduct the second-order factor analysis to know if there is any significant relationship among the exogenous hidden variable of entrepreneurial education system in techno-vocational high schools and 9 related dimensions as the endogenous hidden variable. For this purpose, the second-order factorial model was executed under standard approximation and significant ttest. The results of execution of model of entrepreneurial education system in technovocational high schools and related dimensions are given in Table 5.

Table 5- The results of execution of model of entrepreneurial education system and related dimensions

\begin{tabular}{|l|l|l|l|l|}
\hline Hypothesis & $\begin{array}{l}\text { Standard } \\
\text { coefficient } \\
(\mathbf{r})\end{array}$ & $\mathbf{r}^{2}$ & Result \\
\hline
\end{tabular}




\begin{tabular}{|l|l|l|l|l|}
\hline $\begin{array}{l}\text { Entrepreneurial education system } \rightarrow \text { Training of } \\
\text { entrepreneurship }\end{array}$ & 0.83 & 0.68 & 8.45 & Approved \\
\hline $\begin{array}{l}\text { Entrepreneurial education system } \rightarrow \text { psychological } \\
\text { features of trainees }\end{array}$ & 0.84 & 0.70 & 12.18 & Approved \\
\hline $\begin{array}{l}\text { Entrepreneurial education system } \rightarrow \text { educational and } \\
\text { occupational counseling }\end{array}$ & 0.90 & 0.81 & 12.54 & Approved \\
\hline $\begin{array}{l}\text { Entrepreneurial education system } \rightarrow \text { Leadership } \\
\text { style, management and organization of techno- } \\
\text { vocational high schools }\end{array}$ & 0.94 & 0.88 & 12.37 & Approved \\
\hline $\begin{array}{l}\text { Entrepreneurial education system } \rightarrow \text { Relationship } \\
\text { with industry and commercial and administrative } \\
\text { skills }\end{array}$ & 0.83 & 0.68 & 12.47 & Approved \\
\hline $\begin{array}{l}\text { Entrepreneurial education system } \rightarrow \text { Paying attention } \\
\text { to content }\end{array}$ & 0.87 & 0.75 & 12.27 & Approved \\
\hline $\begin{array}{l}\text { Entrepreneurial education system } \rightarrow \text { Developing } \\
\text { entrepreneurial skills in leaners }\end{array}$ & 0.84 & 0.70 & 10.22 & Approved \\
\hline $\begin{array}{l}\text { Entrepreneurial education system } \rightarrow \text { Educational } \\
\text { climate and equipment }\end{array}$ & 0.80 & 0.64 & 12.42 & Approved \\
\hline $\begin{array}{l}\text { Entrepreneurial education system } \rightarrow \text { Teaching } \\
\text { method }\end{array}$ & 0.82 & 0.67 & 11.64 & Approved \\
\hline
\end{tabular}

Table (5) shows results of testing second-order factor analysis. Table (5) indicates standard coefficient $(r)$, the offered causal relationship among variable of entrepreneurial education system in techno-vocational high schools and related dimensions, $r^{2}$ and $t$-value. The results of above-said table and fitness indices of the second-order model (AGFI=0.91; GFI=0.90, $\left.x^{2} / d f=2.60, \mathrm{RMSEA}=0.079\right)$ indicated that this model was well fitted and identified variables cloud properly measure construct of entrepreneurial education system in technovocational high schools and the given tool possessed suitable construct validity. The findings suggest significance effect coefficient in all 9 identified variables by variable of entrepreneurial education system in techno-vocational high schools and these variables can interpret entrepreneurial education system in techno-vocational high schools.

\section{Has questionnaire of entrepreneurial education system in techno-vocational high schools the adequate validity?}

Validity is one of the features of measurement tool. The given concept is concerned with this point that how much measurement tool could produce the same results under the identical conditions. One of the most common techniques for analysis of reliability of questionnaire is Cronbach alpha coefficient. The Cronbach alpha coefficient was utilized to compute reliability (internal consistency of questions) in the current study. The given results are presented in Table (6).

Table 6- The Cronbach alpha coefficient for questionnaire of entrepreneurial education system in techno-vocational high schools and related variables

\begin{tabular}{|l|c|c|}
\hline \multicolumn{1}{|c|}{ Variables } & $\begin{array}{c}\text { Number of } \\
\text { questions }\end{array}$ & Cronbach alpha \\
\hline Training of entrepreneurship & 14 & 0.89 \\
\hline
\end{tabular}




\begin{tabular}{|l|c|c|}
\hline Psychological features of trainees & 9 & 0.87 \\
\hline Educational and occupational counseling & 6 & 0.79 \\
\hline $\begin{array}{l}\text { Leadership style, management and organization of } \\
\text { techno-vocational high schools }\end{array}$ & 6 & 0.89 \\
\hline $\begin{array}{l}\text { Relationship with industry and commercial and } \\
\text { administrative skills }\end{array}$ & 6 & 0.89 \\
\hline Paying attention to content & 6 & 0.79 \\
\hline Developing entrepreneurial skills in leaners & 5 & 0.74 \\
\hline Educational climate and equipment & 3 & 0.73 \\
\hline Teaching method & 2 & 0.93 \\
\hline Total & 59 & 0.88 \\
\hline
\end{tabular}

The given results at above suggested fitness of reliability of tool (questionnaire and related variables.

Using Friedman test, the order- preference of variable of entrepreneurial education system was analyzed in techno-vocational high schools and their results are visible in Table (10).

Table 10- The results of Friedman test regarding the order- preference of variable of entrepreneurial education system in techno-vocational high schools

\begin{tabular}{|c|c|c|c|}
\hline Component & Mean rank & Component & Mean rank \\
\hline $\begin{array}{l}\text { Psychological features of } \\
\text { trainees }\end{array}$ & 6.08 & Teaching method & 4.96 \\
\hline Paying attention to content & 5.62 & $\begin{array}{l}\text { Relationship with industry and } \\
\text { commercial and administrative } \\
\text { skills }\end{array}$ & 4.83 \\
\hline $\begin{array}{l}\text { Developing entrepreneurial } \\
\text { skills in leaners }\end{array}$ & 5.36 & $\begin{array}{l}\text { Leadership style, management } \\
\text { and organization of techno- } \\
\text { vocational high schools }\end{array}$ & 4.35 \\
\hline $\begin{array}{l}\text { Educational and occupational } \\
\text { counseling }\end{array}$ & 5.22 & $\begin{array}{c}\text { Educational climate and } \\
\text { equipment }\end{array}$ & 3.38 \\
\hline Training of entrepreneurship & 5.20 & Sig $=0.001$ & $X=175.534$ \\
\hline
\end{tabular}

The results derived from statistical data analysis by Friedman test indicate that the priority of variables of entrepreneurial education system in techno-vocational high schools include significant difference at confidence level $99 \%$. It can be implied that variable of psychological characteristics of trainees has the highest priority among the techno-vocational high schools while variable of educational climate and equipment has the lowest rank. The variables of educational content, skill- training, educational and occupational counseling and training and teaching methods have the subsequent rank after variable of potentials and characteristics of trainees. Likewise, Chi-2 test value has been estimated doubly (175.534) and at the favorable significant level ( $\mathrm{Sig}=0.001)$. in other words, there is significant difference between variables of entrepreneurial education system in techno-vocational high schools.

\section{Discussion and conclusion}


The results of analysis were identified in qualitative section with the related corrections in quantitative part using exploratory factor analysis by employing Varimax rotation technique in 9 variables of entrepreneurial education system in techno-vocational high schools (entrepreneurial education, psychological characteristics of trainees, educational and occupational counseling, leadership style, management and organization of technovocational schools, relationship with industry and commercial and administrative skills, paying attention to the contents, developing entrepreneurial skills in learners and educational climate and equipment and teaching method) for which there was significant relationship between all variables and entrepreneurial education system in techno-vocational high schools. In other words, all 9 identified variables have potential for prediction of variable of entrepreneurial education system in techno-vocational high schools.

All of the identified variables play basic role in an educational system. It necessitates for a suitable input and process in order to have appropriate product and output that can be followed by positive social, economic and cultural outcome etc. in an educational system so it has been referred to characteristics of trainees and capable mentors concerning entrepreneurship and educational climate and equipment as the input of educational system and by teaching method, content, activities, management, counseling and communications as main processes of educational system in this study. Review on educational systems and their curricular planning also shows that these variables are addressed as training software among curricular elements. It is necessary for the educational and curricular planners and executives to pay more attention to these elements for upgrading quality of entrepreneurial trainings and favorable product and output by knowledge, and entrepreneurial approach, spirit. The research findings are consistent with the results of domestic and foreign studies. The results of this investigation are aligned to the great extent with the findings of study done by Ojaghi et al. (2016) on higher education titled 'Presentation of a conceptual model of micro and macro elements of entrepreneurial education system' in which they indicated the entrepreneurial education system has been affected by goals of entrepreneurial training, content of entrepreneurship courses, plans and policies of universities and higher education centers, skills of entrepreneurial instructors and mentors and teaching method. The results of this study are also consistent with the findings of survey conducted by Naderi et al. (2015) under title of 'Conceptual modeling for effect of entrepreneurial training variables on attitude of trainees toward business in techno-vocational high schools' in which they assumed entrepreneurial training components as some variables including personality characteristics of trainees, features of mentors, educational climate and equipment, transformational leadership style, educational and occupational counseling, educational content, teaching methods and training patterns of trainees in the family. The findings of the present research are compliant with the results of investigation, to the great extent, done by Shamsudin et al. (2016) titled 'Critique and analysis on entrepreneurial training policies and methods in Malaysia' in which they showed that the government has been focused on these dimensions: Improvement of current entrepreneurial educational policies, proposing various 
entrepreneurial plans to increase number of young entrepreneurs and necessity for empowerment of entrepreneurial education among the graduates. Rauch and Hulsink (2015) also explored effect of entrepreneurial training in entrepreneurship behavior. The findings indicated that entrepreneurial training might be effective, especially in students who participated in entrepreneurship courses and this indicated perceived attitude and behavioral control at high level. The findings in the present research have also mentioned entrepreneurial education as one of the main components of entrepreneurial education system in techno-vocational high schools and it is consistent with the results of their studies.

The results derived from statistical data analysis by Friedman test indicate that there is significant difference between variables of entrepreneurial education system in technovocational high schools at confidence level 99\%. It can be mentioned that among these techno-vocational high schools, variable of psychological characteristics of trainees has the highest rank and the variables of educational content, educational and occupational counseling possess the subsequent ranks after psychological characteristics with approximately close mean ranks while variable of educational climate and equipment has the lowest rank. The results of this study are consistent with findings in some studies and also inconsistent with the other investigations in this regard.

The results of this study are totally consistent with the findings of investigations done by Bagherifar and Salehi (2016) under title of 'Skill-training challenges and education for entrepreneurial trainees in techno-vocational high schools: A study done by phenomenological method' that showed that variable of non-attraction of talented and interested students had the highest frequency among skill-training challenges based on attitude of trainees. The findings of current study are aligned with the results derived from survey of Sharifzadeh and Abdullah Zadeh (2015), titled 'Variables of developing entrepreneurial education in agricultural higher education system', in ranking of academic entrepreneurial markers the variables of education (different methods of students' visits and scientific tours from businesses, factories, industries and production units and successful entrepreneurial and business models in agricultural sector, considering students' business projects within agricultural operation courses, and related projects etc., adaption of creative teaching techniques in classrooms, formulation of business project by students individually and in group and clerkship by entrepreneurial nature) have acquired the highest priority, to some extent. The training variable is placed in subsequent priorities after personality potential and features in this study of course and the findings seem to be almost close to each other.

\section{References:}

-Aghababaeian, Parimaz, Jamshidi, Noormohammadian, Mojdeh (2013). The role of education and training in training of entrepreneurial personnel and entrepreneurship in educational system, $1^{\text {st }}$ regional conference on entrepreneurship and commercialization, 
Islamshahr, SAMA Technical and Professional faculty, Islamic Azad University, Islamshahr Branch.

-Ojaghi, Saba, Rezayee, Bijan, Naderi, Nader, Jafari Habib (2016), Presentation of a conceptual model of micro and macro variables of entrepreneurial education system, Journal of entrepreneurship in agriculture, $3^{\text {rd }}$ vol., No. 4, winter, pp. 39-54.

-Alvani, Seyed Mehdi, Moghimi, Seyed Mohammad, Azar, Adel, Rahmati, Mohammad Hossein (2011). Policy making in entrepreneurial education system in Iran, Monthly of labor an community, vol. 140, pp. 5-30.

-Aminzadeh, Leila, Seifi, Mohmmad, Faghihi, Alireza (2015), Evaluation of high school curricula (techno-vocational) by addressing entrepreneurship subject based on attitude of experts, two quarterlies of theory and practice in curriculum, $3^{\text {rd }}$ year, vol. 6 , autumn \& winter, 2015, pp. 143-164.

-Bagherifar, Ali Akbar, Salehi, Keivan (2016). Skill- training challenges and education of entrepreneurial trainees in techno-vocational high schools: A study done by phenomenological method, Tehran: The $5^{\text {th }}$ national conference and $4^{\text {th }}$ international summit on skill training and employment.

-Pahlavi, Hassan (2014), Conceptualization of entrepreneurial education: Analysis on dimensions and variables of entrepreneurial education by focusing on entrepreneurial training in organization, $3^{\text {rd }}$ national annual conference on modern management sciences, Gorgan, 2014.

-Khosravi, Bahman, Irvani, Houshang, Hosseini Seyed Mahmud, Movahed Mohammadai, Hamid (2007), Identification and analysis of effective educational elements on entrepreneurial potential of students in Applied Sciences Higher Education Centers. Quarterly of agricultural sciences in Iran, series 38, vol. 2, pp. 207-217.

- Dahmardeh Ghalehno, Samira, Fetanat Fard Haghighi, Milad, Gharayeepour, Reza (2015), Analysis of entrepreneurial education models, $1^{\text {st }}$ conferemce on management and entrepreneurship under resistive economic conditions, Mashhad.

-Rahmati, Mohammad Hossein, Moghimi, Seyed Mohammad, Alvani, Seyed Mehdi (2010), Analysis on policy-making system for informal entrepreneurial education in Iran, Quarterly of entrepreneurial development, $3^{\text {rd }}$ year, vol. 9, autumn, pp. 7-35.

-Rouhi (2014), Review of effective factors in formation of entrepreneurship among high school students (Case study: Baharestan city- Area No 1), MA thesis, Payam-E-Noor University (PNU), West Branch.

-Saeedikia, Mehdi (2016), Entrepreneurship, Tehran: Aha Pub. 
-Saeedi Mehrabad, Mohammad, Mohtadi, Mohammad Mehdi (2008), Effect of entrepreneurial training on developing entrepreneurial behaviors (Case study: Entrepreneurial trainings held by Ministry of Labor and Social Affairs), Quarterly of entrepreneurial development, $1^{\text {st }}$ year, vol. 2, winter, pp. 57-73.

-Shah Hosseini, Ali (2009), Entrepreneurship in practice, Tehran: Ayeezh Pub.

-Sharifzadeh, Mohammad, Abdullah Zadeh, Gholam Hossein (2015), Variables of developing entrepreneurial education in agricultural higher education system, Quarterly of management research in agricultural training, vol. 32, spring, pp. 96-112.

-Shekari Abbas, Zarei Sebhati, Ehsan, Yazdkhasti, Ali (2016), The role of Know About Business (KAB) entrepreneurial training pattern in entrepreneurship skills of apprentices in techno-vocational training centers (Case study: Isfahan province), Two quarterlies of theory and practice in curriculum, series 4 , vol. 7, pp. 21-54.

-Mohammad Kazemi, Reza, Ahmadi, Aida, Shahmoradi, Goodarz (2016), Entrepreneurial training appropriate techniques, Tehran: Borhan cultural institute (Madreseh Pub).

-Mazbouhi, Saeed, Sharafi, Mohammad, Moghadam Mina (2012), Entrepreneurial training curriculum: Goal, content, teaching and evaluation method, Journal of innovation and creativity in humanities, $1^{\text {st }}$ year, vol. 3, autumn \& winter, pp. 97-130.

-Naderi, Nader, Amiri, Saba, Delangizan, Sohrab, Jafari, Habib (2015), Conceptual modeling for effect of entrepreneurial training variables on attitudes of trainees toward business in techno-vocational high schools, Journal of entrepreneurship in agriculture, $2^{\text {nd }}$ vol., pp. 17-34.

-Vatankhah, Nasim, Rezayee Moghadam, Kourosh (2015), Variables and barriers of establishment of entrepreneurial faculty based on attitude of member and non-member students in agricultural faculty in University of Shiraz, Journal of cooperation and agriculture, $4^{\text {th }}$ year, vol. 15 , autumn, pp. 17-40.

-Yadollahi Farsi, Jahangir (2009), Encyclopedia of entrepreneurship, Tehran: Iranian Encyclopedia- Writing Foundation, Institute of labor and social security, viols. $1 \& 2$.

\section{Latin sources:}

-Gutiérrez, J. G., \& Baquero, J. E. G. (2017) New cross-proposal entrepreneurship and innovation in educational programs in third level (tertiary) education. Contaduría y Administración, 62 (1), 239-261. -Manero, P. V., \& Egido, M. P. (2014) The Concept of Entrepreneur in Education: A Pedagogical Analysis. Procedia- Social and Behavioral Sciences, 139, 153-159.

-Oguz, A., \& Aydin, U. (2012) Education System in Knowledge Society 
and Model of Innovative Entrepreneur. Procedia- Social and

Behavioral Sciences, 47, 619-623.

-Rauch, A., \& Hulsink, W. (2015) Putting entrepreneurship education

where the intention to act lies: An investigation into the impact of entrepreneurship education on entrepreneurial behavior. Academy of

Management Learning \& Education, 14 (2), 187-204.

-Shamsudin, S. F. F. B., Al Mamun, A., Nawi, N. B. C., Nasir, N. A. B.

M., \& Zakaria, M. N. B. (2016) Policies and Practices for

Entrepreneurial Education in Malaysia: A Review. Mediterranean

Journal of Social Sciences, 7 (2), 36. 